\title{
ESTADOS UNIDOS E BRASIL NO GANTOIS $O$ poder e a origem transnacional dos Estudos Afro-brasileiros
}

\section{Livio Sansone}

\author{
Tradução de Fabio Baqueiro
}

Este artigo inicia com uma dupla proposição. Nos Estados Unidos, os Estudos Africanos, como um campo autônomo de pesquisa acadêmica, originam-se no âmbito dos Estudos Afro-americanos. O Brasil, e especialmente a Bahia, que tem a maior porcentagem de afrodescendentes no país, tiveram um lugar de destaque nesse processo. $\mathrm{O}$ estilo, $\mathrm{o}$ jargão, as prioridades, as modas intelectuais e a metodologia dos Estudos Africanos e dos Estudos Afro-americanos estiveram portanto inter-relacionados, especialmente no período entre 1930 e 1960, quando o processo de descolonização africana começou a ganhar corpo e novas agendas de pesquisa foram definidas. A segunda parte da proposição é a de que não há história da antropologia e de disciplinas correlatas que seja exterior à geopolítica do conhecimento. Isso implica que há um norte e um sul globais nas trocas intelectuais, com relações

Artigo recebido em 23/03/2011

Aprovado em 17/12/2011 complexas entre pesquisadores do norte e do sul em que os últimos são, na maioria das vezes embora não exclusivamente, fornecedores de evidência etnográfica, contatos locais e intuições sagazes, mas raramente a fonte de generalizações teóricas universalmente válidas -, e que a posição do pesquisador nessa troca é indicativa de sua abordagem e de sua agenda. Qualquer leitura de um relatório etnográfico deve levar em conta esse contexto e essas relações de poder. $\mathrm{O}$ texto que se segue busca corroborar ambas as partes dessa proposição. ${ }^{1}$

Entre 1941 e 1943 a cidade de Salvador, na Bahia, tornou-se o local de uma batalha entre dois diferentes entendimentos sobre a integração racial nos Estados Unidos e sobre o lugar da África nesse processo. Franklin Frazier, o mais conhecido sociólogo negro da época, que já havia então publicado A família negra nos Estados Unidos (Frazier, 1966), estava empenhado em uma discussão com o igualmente famoso antropólogo, branco e judeu, 
Melville Herskovits, sobre as "origens" da chamada "família negra". Para tornar as coisas ainda mais complicadas, ambos baseavam seus argumentos em trabalhos de campo realizados entre os mesmos informantes: o povo de santo do mesmo terreiro de candomblé em Salvador, o prestigiado e "tradicional" terreiro do Gantois, de nação queto-iorubá. A meio caminho entre os dois estava o linguista Lorenzo Dow Turner, que publicaria mais tarde seu livro seminal sobre as influências africanas no "gullah", o idioma falado pelos habitantes das ilhas costeiras da Carolina do Sul e da Geórgia, nos Estados Unidos (Turner, 2003). Turner era amigo de Frazier, mas suas teorias acadêmicas estavam mais próximas das de Herskovits.

As visões opostas de Frazier e Herskovits alcançaram grande publicidade com a publicação, na American Sociological Review, de um artigo de Frazier (1942a), seguido de uma resposta de Herskovits (1943) e de uma réplica de Frazier (1943). O debate destacava aspectos interessantes relativos à forma pela qual a antropologia se define como disciplina, em comparação com a sociologia, e também à construção dos Estudos Afro-brasileiros como um campo de pesquisa acadêmica. É a história da tensão entre um sociólogo e um antropólogo norte-americanos, ambos recorrendo aos serviços de intermediários e "guardiōes" brasileiros, que eram, por sua vez, partes interessadas na contenda.

A pesquisa ainda demonstra como, já naquela época, o estilo e o vocabulário de sociólogos e antropólogos - mais seco e sóbrio no caso dos primeiros e enfaticamente romântico no caso dos últimos - se relacionavam com abordagens radicalmente diferentes do mesmo fenômeno, neste caso as "origens" e a causalidade de formas culturais negras no novo mundo. A cultura e a estrutura familiar negras seriam o resultado da escravidão e mais tarde a adaptação à pobreza? Ou seriam o resultado de africanismos, de formas tradicionais africanas de vida e de cultura adaptadas ao novo mundo? Por trás dessas duas abordagens residem duas diferentes perspectivas da luta antirracista: o antropólogo (Herskovits) e o linguista (Turner) destacando as diferenças culturais e tomando em consideração a força da cultura e sua capacidade de resiliência, contra o sociólogo (Frazier) enfatizando a univer- salidade da condição humana e o caráter intrinsecamente mutável de todas as formas culturais e sociais. A diversidade cultural contra a universalidade da condição humana; a pessoa negra merecendo respeito por sua cultura e personalidade serem intrinsecamente diferentes, ou, ao contrário, por ser um ser humano como qualquer outro. Tais atitudes, devo reiterar, estão associadas a diferentes agendas e posicionamentos políticos. O princípio dessa diferença é a forma pela qual a libertação do racismo é vista: como resultante da luta de indivíduos para derrotá-lo, ou como o efeito do reconhecimento das diferenças e da singularidade da cultura dos negros - que eram vistos então, em grande medida, como um coletivo sem individualidade.

Reconstruir a pesquisa desses três acadêmicos no Brasil, especialmente em torno da cidade de Salvador, é importante para entender o período que precedeu a escolha do Brasil, no início da década de 1950 , como o palco do primeiro grande projeto de pesquisa da Unesco, o qual pretendia demonstrar que as relações raciais podiam ser harmoniosas. $\mathrm{O}$ projeto foi concebido para apoiar empiricamente a famosa Declaração sobre raça da instituição, que veio à luz em 1950 como reação ao Holocausto e à monstruosidade da Segunda Guerra Mundial e à implantação do apartheid em $1948 .^{2}$ Cruciais para sua realização foram as atividades de Alfred Métraux na Unesco, que assumiu como objetivo a criação de uma agenda antirracista global - um esforço que se provou ser um dos principais impulsos para a criação dos Estudos Afro-brasileiros e, de modo mais geral, para o desenvolvimento e a institucionalização das ciências sociais no Brasil. ${ }^{3}$

Quando, no início da década de 1950, a Bahia se tornou o palco desse grande esforço para estudar as relaçōes raciais no Brasil, a pesquisa foi encampada como uma parceria entre a Universidade Colúmbia e a Universidade da Bahia, com o apoio ativo do enérgico secretário estadual de Educação, Anísio Teixeira. ${ }^{4}$ De fato, a percepção de que a Bahia e o Brasil eram os lugares "ideais" para um tal projeto de grandes proporções e politicamente relevante sobre a cultura negra e as relações raciais no novo mundo foi o resultado de um processo mais longo, iniciado na década de 1930 (Romo, 2009 e 2010), que se baseou em uma sinergia entre as políticas culturais 
do Estado Novo, a introdução da sociologia e da antropologia como disciplinas acadêmicas nas universidades brasileiras e a maneira como muitos estudiosos estrangeiros, especialmente norte-americanos e alemães, fugindo seja da segregação racial seja do nazismo, assumiram a representação oficial do Brasil como uma democracia racial. Como demonstrou o livro organizado por David Hellwig (1992), a partir dos anos de 1920 tanto acadêmicos como intelectuais negros baseados nos Estados Unidos passaram a retratar o Brasil como um alter ego da segregação vivida em seu país. Além deste livro, podem-se consultar as cartas enviadas por Du Bois aos presidentes brasileiros, ${ }^{5}$ assim como artigos de Ralph Bunche, Richard Pattee e Alain Locke, entre outros, em diversos periódicos norte-americanos, tais como Journal of Negro History, Journal of Negro Education, Crisis e Phylon. Para esses estudiosos afro-americanos, o Brasil era um modelo positivo para o futuro das relaçôes raciais nos Estados Unidos.

Vejamos agora como Frazier, Herskovits e Turner contribuíram, possivelmente sem estarem completamente cientes das consequências, tal como muitos outros acadêmicos do norte de então, para criar as condiçōes para a celebração internacional da suposta ausência de racismo na sociedade brasileira por parte do regime populista e autoritário do Estado Novo. Não que as hierarquias sociais e raciais não estivessem mudando em Salvador na década de 1930; a sociedade estava se tornando ligeiramente menos hierárquica, e, pela primeira vez, um componente significativo da elite intelectual começou a desenvolver uma atitude positiva para com expressóes culturais de origem africana na sociedade baiana. Em termos culturais, a África estava começando a ser encarada como um bônus - um recurso na coluna dos ativos -, depois de ter passado séculos como um ônus - na coluna dos passivos. Um exemplo dessa mudança foi a organização, por Édison Carneiro e Arthur Ramos, do II Congresso Afro-brasileiro, em 1937, que marcou sua diferença do primeiro, organizado em 1935, em Recife, por Gilberto Freyre, ao incluir palestrantes oriundos do que era então conhecido como a comunidade afro-baiana. Martiniano Eliseu do Bonfim, importante presença dos famosos e tradicionais terreiros de candomblé Axé Apo Afonjá e Casa Branca, foi escolhido como presidente honorário do congresso. Alguns anos mais tarde, Turner, durante sua estadia em Salvador, tiraria notáveis fotografias desta personagem transatlântica que corporificava a importância da Baía do Benim na história cultural e religiosa da Bahia - algo que, mais tarde, se tornaria uma importante fonte de inspiração na busca pela autenticidade africana como base para o poder e a autoridade no sistema religioso do candomblé na Bahia e em outras partes, tão sagazmente descrito por Beatriz Góis Dantas (1998), entre outros. Um olhar atento aos anais do congresso revela uma combinação singular de intelectuais ditos regionais, de renome nacional, e internacionais. Herskovits, não podendo comparecer, enviou um artigo para ser lido em seu nome. Apresentado como conferência principal, acabou por ser o primeiro de uma série de artigos selecionados a ser publicado mais tarde em formato de livro (Yelvington, 2007).

Como exemplos da forma como a Bahia forneceu uma atmosfera hospitaleira para acadêmicos estrangeiros, especialmente os dos Estados Unidos, podemos começar pela menção a Donald Pierson, na época um estudante de doutorado em sociologia na Universidade de Chicago sob a orientação do destacado professor Robert Park, que chegou a Salvador em 1936 para um trabalho de campo pioneiro entre a comunidade negra (Corrêa, 1987). ${ }^{6}$ Pierson estava convencido, em grande medida, de que era a classe, e não a raça, que importava na Bahia, e que qualquer sinal de racismo que pudesse

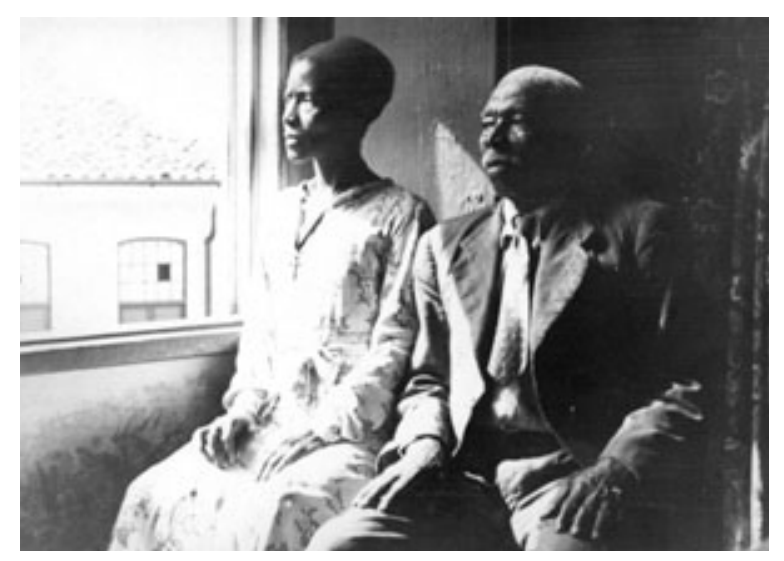

Martinano do Bomfim e esposa.

Fonte: Lorenzo Dow Turner Papers, Anacostia Museum, Smithsonian Institute. 
ser notado devia ser considerado muito mais uma herança da escravidão do que um sinal da modernidade. Ele fez diversas entrevistas, fotografias e um levantamento detalhado sobre a classificação racial e sua terminologia na Bahia (Pierson, 1942).

Aparentemente, graças à rede de informantes mobilizada por Pierson, Ruth Landes, uma antropóloga norte-americana, também escolheu Salvador para sua pesquisa de pós-doutorado, originalmente concebida para tratar da matriarcalidade no candomblé. Landes, cuja orientadora era ninguém menos que Ruth Benedict, aceitou a ajuda de Pierson para fazer contatos e receber orientações para sua pesquisa na Bahia. Ela não dependeu do apoio do famoso antropólogo baiano Arthur Ramos, a principal pessoa de contato indicada pela diretora do Museu Nacional no Rio de Janeiro, Heloísa Torres. "Dona Heloísa", como era conhecida, era a guardiã quintessencial da antropologia brasileira (Corrêa e Mello, 2009; Corrêa, 2003). ${ }^{7}$ Aparentemente, essa foi uma das três razões que rendeu a Landes a inimizade tanto de Arthur Ramos como de Melville Herskovits ao fim de sua pesquisa. As outras duas foram o fato de ela ter supostamente descrito de forma exagerada a importância dos homossexuais no candomblé (algo que deveria ter sido evitado em uma época em que os antropólogos brasileiros tentavam convencer o governo federal a aceitar o candomblé como uma religiāo "decente") e seu envolvimento romântico com o bem conhecido Édison Carneiro. Esse relacionamento infringiu dois tabus na Bahia, um do consulado norte-americano (ter um caso com um homem negro) e outro da elite baiana (ter um caso com um simpatizante do comunismo) (ver Cole, 1994; Corrêa, 2002 e 2003). Landes deixou o Brasil assim que terminou seu trabalho de campo. Efetivamente, de acordo com o pesquisador francês Pol Briand (em uma recente comunicação pessoal), ela foi deportada e viajou com o coração partido. Édison Carneiro tentaria reencontrá-la, mas nunca seria capaz de obter um visto de entrada nos Estados Unidos (uma recusa possivelmente relacionada com suas inclinaçôes políticas). Sobre isso, a correspondência entre Landes e Carneiro, depositada no Arquivo Antropológico Nacional em Washington, DC (ver NAA, Ruth Landes Papers), é reveladora. Pierson, ao contrário,

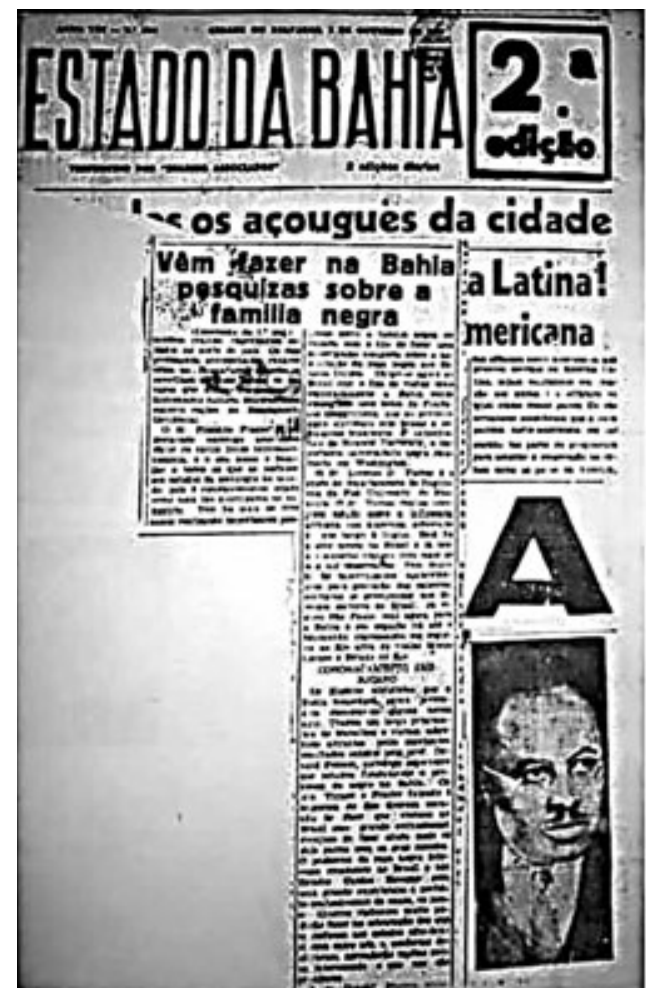

Fonte: E. Franklin Frazier Papers, MoorlandSpingarn Documentation Center, Howard University, Washington, DC.

permaneceu no Brasil por muitos anos e tornou-se uma figura importante para a institucionalização da sociologia como uma disciplina acadêmica no país, tendo ensinado na Escola Livre de Sociologia, em São Paulo até o final dos anos de 1950. Em resumo, Salvador e sua comunidade afro-baiana foram, naqueles dias, uma importante encruzilhada da sociologia e da antropologia internacionais, assim como uma importante fonte de inspiração para o pensamento antirracista (Corrêa, 1987).

Em 8 de dezembro de 1940, Lorenzo Dow Turner chegou a Salvador junto com o sociólogo Franklin Frazier. Sua chegada foi anunciada na primeira página dos principais jornais baianos. ${ }^{8}$ Eles haviam estado brevemente no Rio de Janeiro e tinham ido a São Paulo, onde fizeram uma palestra na Escola Livre de Sociologia, a convite de Pierson. Frazier vinha da Universidade Howard, e Turner, da Universidade Fisk (Landes passara um período em Fisk antes de vir à Bahia). Frazier obtivera uma bolsa da Fundação Guggenheim - na verdade, Du 

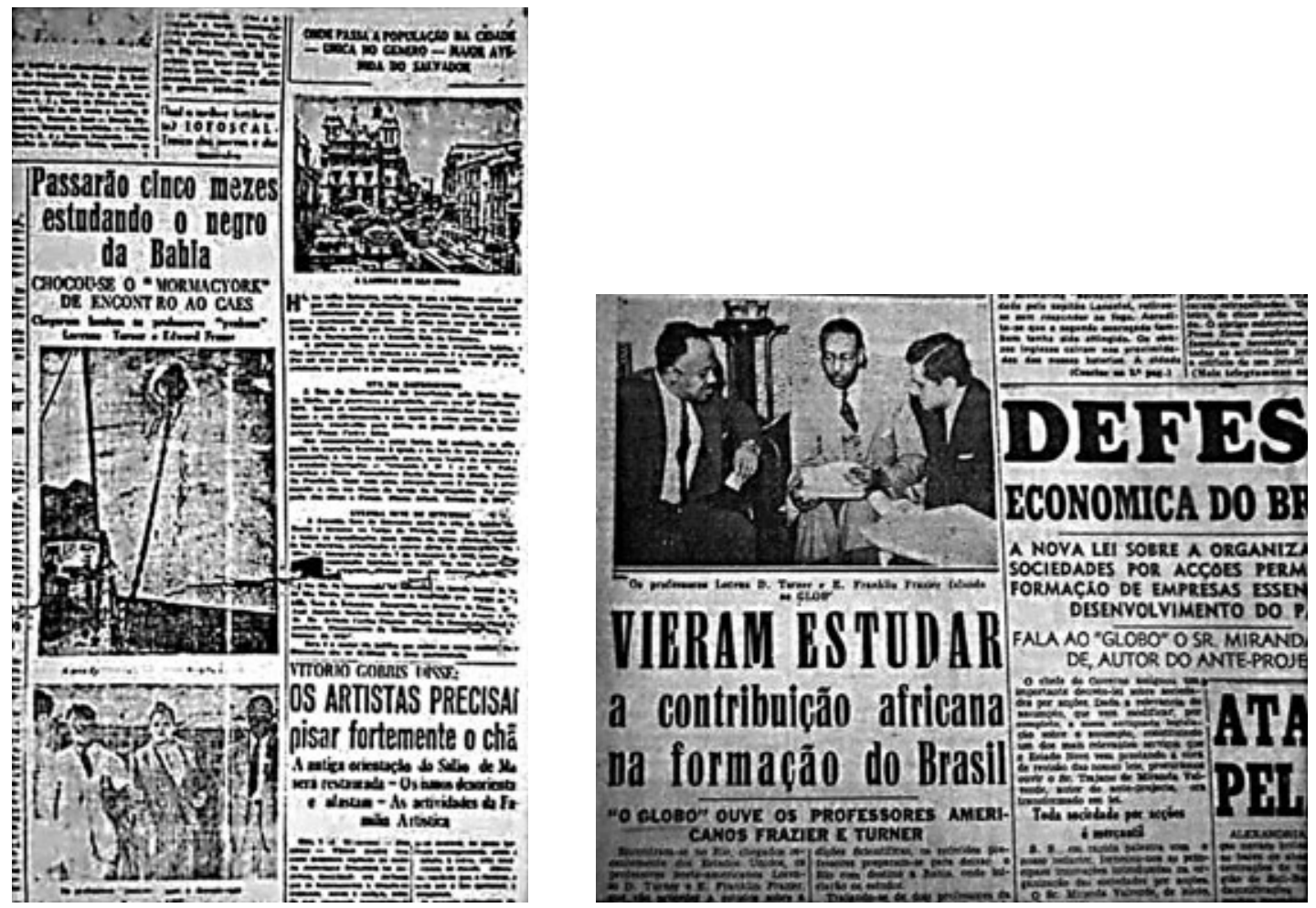

Fonte: E. Franklin Frazier Papers, Moorland-Spingarn Documentation

Center, Howard University, Washington, DC.

Bois havia escrito a Frazier para congratulá-lo por ter sido o primeiro negro a receber essa bolsa tão prestigiosa. Turner recebera uma bolsa da Fundação Rosenwald, especializada no financiamento de pesquisadores negros. Como pode ser lido nos relatórios de avaliação das candidaturas às bolsas dos três acadêmicos, sua visita ao Brasil poderia de fato contribuir para diversas atividades diplomático-culturais patrocinadas pela "política de boa vizinhança” por meio da qual o governo norte-americano e, especialmente, a Fundação Rockefeller estavam tentando ampliar o grau de entendimento mútuo entre os dois países. A agenda oculta dessa política era contrabalançar a neutralidade de parte do governo brasileiro nos primeiros estágios da Segunda Guerra Mundial. Considere-se que, para a opinião pública brasileira da época, os Estados Unidos eram a terra do racismo institucionalizado. $\mathrm{O}$ argumento de muitos na frente neutralista brasileira era: "por que combater o nazismo alemão e defender a segregação americana?” (Williams, 2001, pp. 192-250). ${ }^{9}$
Como parte deste grande esforço pré-guerra, que incluía ainda cooperação no campo da pesquisa científica e na saúde pública, dois norte-americanos famosos foram enviados para o Brasil: Orson Welles e Walt Disney. O primeiro chegou em 1942 e durante seis meses filmou intensivamente, em seu estilo característico, cenas da cultura popular, o que resultou em um brilhante documentário curta-metragem intitulado Quatro homens em uma jangada, que deveria ser o primeiro episódio de um documentário mais longo, recheado de cenas do carnaval carioca, intitulado $E^{\prime}$ tudo verdade. ${ }^{10}$ A maior parte das filmagens retratava o Brasil como majoritariamente negro e mulato. As imagens do carnaval do Rio de Janeiro, em especial, demostravam tratar-se de uma celebração negra e de classe baixa. Devido a esse "enegrecimento" do carnaval, associado ao que era então considerado um comportamento social e uma relação com a bebida extravagantes, Orson Welles jamais chegou a desfrutar da glória que merecia como documentarista e foi mandado 
de volta aos Estados Unidos prematuramente. Em 1993, sua obra inacabada foi reunida em um novo documentário, produzido na França, que também recebeu o título É tudo verdade. ${ }^{11}$

Com Walt Disney a história foi completamente diferente. Em 1942, ele produziu sua animação Saludos amigos. Sua animação de 1944, Você já foi à Bahia, lançou a personagem Zé Carioca, o papagaio trapaceiro e espirituoso que deveria representar a alma dos brasileiros. ${ }^{12}$ Esse estereótipo tropical apeteceu muito mais à elite brasileira e fez boa figura aos olhos dos planejadores da política de boa vizinhança.

Vale a pena recordar que naqueles anos atribulados o Brasil era concebido como um possível refúgio seguro não apenas pelos negros norte-americanos, mas também pelos judeus europeus. Frazier e Turner vieram ao Brasil no mesmo ano em que o famoso escritor austríaco judeu Stefan Zweig e sua esposa chegaram ao Rio de Janeiro. Ao que parece, suas primeiras impressões foram semelhantes e positivas: eles ficaram encantados em observar interaçôes inter-raciais em escolas e nas casas das crianças. Há evidência de que essas representações favoráveis da integração racial formuladas por intelectuais estrangeiros negros e judeus influenciaram-se mutuamente (Zweig e Zweig, 2010; Dines, 2009).

A propósito, nos documentos de Frazier depositados no Centro de Pesquisa Moorland-Spingarn da Universidade de Howard podem-se encontrar diversas pastas onde Frazier guardava recortes de jornais relativos a episódios de linchamentos nos Estados Unidos, reunidos no período imediatamente anterior à sua viagem para o Brasil. Ele estava algo obcecado pelo linchamento de afro-americanos e era conhecido sobretudo por promover retaliações contra o racismo cotidiano - por exemplo, processando diversos estabelecimentos segregados por lhe terem impedido a entrada, ou recusando convites de instituições acadêmicas se isso implicasse em se sujeitar a transportes ou instalações públicas segregadas. Não surpreende que, assim que chegou ao Rio de Janeiro, Frazier tenha colecionado brochuras de instituiçôes como o Instituto Central do Povo ou o Orfanato Ana Gonzaga, nas quais eram retratados grupos de crianças racialmente mistos. ${ }^{13}$ No Brasil, o horror deu lugar ao espanto. Tanto Frazier como Zweig tinham deixado para trás horrores - o antissemitismo e a segregação racial. Zweig cometeu suicídio na cidade de Petrópolis, em 1943, junto com sua esposa, depois de publicar o maravilhoso livro Brasil, o país do futuro, e deixando uma carta de desculpas ao povo brasileiro (Spitzer, 1989). Frazier voltou aos Estados Unidos fortalecido em sua convicção de que havia um lugar de humanidade para os negros no novo mundo, no contexto da modernização e da industrialização.

Frazier então já havia conquistado a aceitação em certos círculos do mundo acadêmico e mesmo dentro do governo Roosevelt. Ele veio ao Brasil para apresentar seu famoso livro The black family in the United States, publicado em 1939, e para ministrar palestras sobre a situação da população negra nos Estados Unidos, mas também para coletar material em apoio à sua teoria de que tinham sido a escravidão e a adaptação à pobreza os principais fatores que influenciaram a estrutura familiar da população negra. Com esse propósito, ele viajou direto para uma das regióes que, de acordo com Herskovits, concentrava mais "africanismos": a cidade de Salvador e, mais especificamente, a comunidade em torno de uma das mais tradicionais casas de candomblé, o Gantois. Em sua expedição à Bahia Frazier beneficiou-se da rede tecida por seu conterrâneo e colega sociólogo Donald Pierson, que o apresentou a um conjunto de pessoas-chave na elite intelectual baiana e o advertiu a não confiar demais na antropóloga Ruth Landes - que, como dito anteriormente, tinha infringido o código racial norte-americano e o código social brasileiro ao ter um relacionamento com o intelectual negro de tendências comunistas Édison Carneiro, e por ter sido algo displicente em seu trabalho de campo; além disso, em seu livro, Landes teria exposto exageradamente a homossexualidade nos terreiros, justamente quando Herskovits e Arthur Ramos lutavam para afirmar o candomblé como um objeto antropológico aceitável e como um sistema religioso por direito próprio (Cole, 1994; Fry, 2010).

Durante o trabalho de campo, Frazier, que aparentemente era capaz de entrevistar pessoas em português sem o recurso a um intérprete, juntou-se ao linguista Lorenzo Dow Turner, 
que dispunha de um equipamento sonoro sofisticado que permitiu a gravação de muitas horas de entrevistas com sacerdotes e sacerdotisas do candomblé, assim como de música, lendas e contos. Turner também tirou cerca de duzentas fotografias, incluindo muitos dos informantes de Frazier. Nos anos seguintes, Turner, com a ajuda de assistentes africanos, transcreveu centenas de páginas de lendas em línguas africanas, a maioria em iorubá, que tinha coletado no Brasil. Essa pesquisa tomaria mais tarde a forma de três artigos (Turner, 1943, 1957, 1958), além das gravações, das transcrições de lendas e das fotografias. É uma pena que, por conta de diversas limitaçôes, inclusive financeiras, e apesar de diversas tentativas, Turner nunca tenha conseguido publicar aquelas transcrições únicas em formato de livro. Margaret Wade-Lewis (2007), em sua minuciosa biografia de Turner, menciona que, efetivamente, ele tinha planos de publicar três livros com o resultado de sua pesquisa de campo no Brasil. Essas transcrições (a Universidade Federal da Bahia dispõe de cópias gentilmente cedidas por David Easterbrook, da Africana Library da Northwestern University) são uma raridade que precisa ser estudada por um linguista ou outro acadêmico iorubá. Não obstante, elas parecem fornecer evidência de que havia línguas africanas de uso corrente na Salvador dos anos de 1940 , e não apenas como parte do vocabulário religioso do candomblé, como ocorre atualmente. ${ }^{14}$

As experiências cotidianas desses estudiosos negros em Salvador foram notáveis e com certeza bastante diferentes da vida cotidiana nos Estados Unidos. Na chegada a Salvador, de navio, eles foram recepcionados pelo cônsul norte-americano no porto (o qual, muito provavelmente, jamais havia dado as boas-vindas a intelectuais negros de tal envergadura antes). Sua chegada foi anunciada nas primeiras páginas de todos os jornais locais, e eles se hospedaram no bem localizado Hotel Palace, no centro (um dos melhores hotéis da cidade, possivelmente o melhor, onde outros intelectuais estrangeiros em visita à cidade também se hospedaram, a exemplo de Ruth Landes). Eles tinham um motorista branco, vestido de terno branco e gravata borboleta, e tinham aulas particulares de português com uma senhora que vivia no burguês Campo Grande. Eles participaram do carnaval e da popular festa de largo em homenagem a Nosso Senhor do Bonfim na companhia de um grupo de garotas de pele clara de classe média, como se pode ver claramente na fotografia feita por Turner na ocasião (cf. col. Lorenzo Dow Turner no Museu Digital da Memória Africana e Afro-Brasileira).

Em outras palavras, tanto Turner como Frazier puderam circular à vontade, não só nos espaços da cultura popular e das religióes tradicionais mas também entre as elites da Bahia. Essa liberdade era muito provavelmente devida à sua cidadania norte-americana e à sua moeda forte.

Sua presença também não passou desapercebida entre a elite intelectual branca; afinal de contas eles eram muito provavelmente os primeiros acadêmicos norte-americanos negros a conduzir pesquisa de campo na Bahia, e talvez no Brasil como um todo. Em uma carta a Melville Herskovits datada de $1^{\circ}$ de dezembro de 1944 , José Valladares, o principal contato do antropólogo na Bahia, descreveu Franklin Frazier como arrogante e como um "mulato frajola". ${ }^{15}$ A elite baiana que tinha recebido tão bem viajantes e acadêmicos norte-americanos brancos aparentemente não ficou tão feliz em dar as boas-vindas a seus colegas negros.

Em agosto de 1941, logo depois do curto trabalho de campo de Frazier e da pesquisa ligeiramente mais longa de Turner, o terreiro do Gantois recebeu a visita de Melville Herskovits, acompanhado de sua esposa Frances e de sua jovem filha Jean. Em 1937, ele já era bem conhecido dos cientistas sociais brasileiros - como dito anteriormente, ele havia enviado um texto para ser lido como conferência principal no II Congresso Afro-brasileiro. Ao que parece indicar um conjunto de fotografias de família que o retratam junto a sua esposa e filha, Herskovits alugou um pequeno apartamento na Pensão Edith, em um edifício que atualmente é conhecido como Casa de Itália, no Campo Grande, bem no centro de Salvador - uma acomodação confortável mas menos no centro dos holofotes que o Palace Hotel. Ele contou com o auxílio de um intérprete de prestígio, o bem-posicionado intelectual José Valladares, um renomado historiador da arte que ocupava o cargo de curador do Museu da 


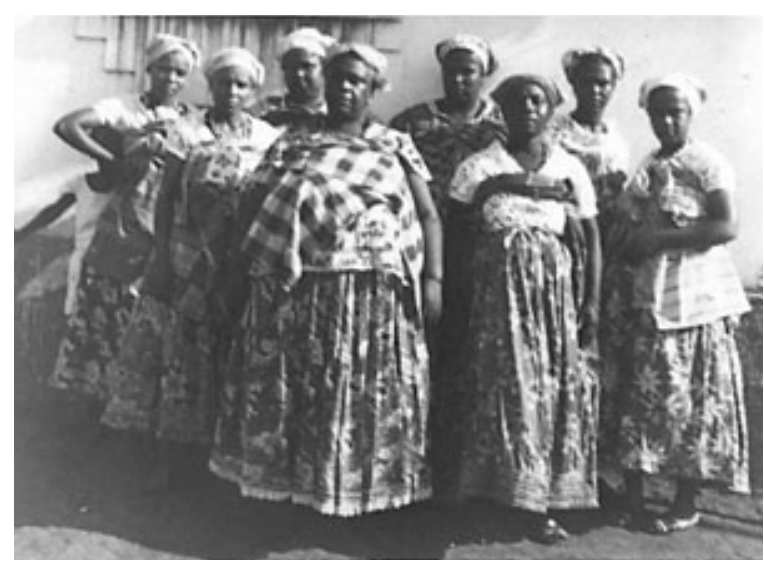

Mãe Menininha e suas Ekedi.

Fonte: Franklin Frazier Papers, Moorland-Spingarn Documentation Center, Howard University.

Bahia e que tinha sido o secretário do II Congresso Afro-brasileiro. Arquiteto, historiador da arte e escritor, ${ }^{16}$ era ainda casado com Gisela, uma norte-americana que tinha formação em antropologia e que se envolveu mais tarde em um dos projetos de pesquisa sobre as relaçôes raciais na Bahia promovido em conjunto pela Universidade da Bahia e pela Universidade Colúmbia sob a égide da Unesco (Wagley, 1952; Azevedo, 1996).

$\mathrm{Na}$ Bahia, Herskovits palmilhou uma rede diferente daquela de Frazier e Turner. Ele tinha conexôes muito mais valiosas com a elite intelectual baiana - alem de José Valladares, outro importante contato era Arthur Ramos, considerado o patrono dos Estudos Afro-baianos, com quem Herskovits vinha mantendo copiosa correspondência, que prosseguiu depois (Guimarães, 2007) - além de contar com o endosso da diretora do Museu Nacional, a famosa dona Heloísa Alberto Torres (Corrêa e Mello, 2009). Herskovits entrevistou mais ou menos as mesmas pessoas que Frazier, mas chegou a conclusões opostas: para ele os africanismos explicavam em linhas gerais os arranjos familiares matrifocais dos negros e pobres baianos. Para Herskovits a matrifocalidade era essencialmente um padrão familiar característico da África Ocidental que se tinha mantido vivo ao longo dos tempos; para Frazier, a matrifocalidade era uma adaptação criativa à vida sob condições sociais incertas, e muito mais uma estratégia de sobrevivência dos pobres em diversas partes do globo do que o resultado de qualquer padrão cultural.

Como se sabe, esse contexto de enfrentamento entre sociologia (Frazier) e antropologia (Herskovits) teria um grande impacto no debate sobre as causas da matrifocalidade de muitas famílias negras, assim como sobre a relação entre pobreza e cultura no seio da população negra dos Estados Unidos - algo especialmente perceptível durante a "guerra à pobreza" empreendida pelo governo Lyndon Johnson (1963-1969).

O trabalho de Turner estava posicionado mais ou menos no meio dessas duas posições, apesar de tender para a noção herskovitsiana de africanismo. Turner acreditava que a força da cultura negra e de sua linguagem residia em sua capacidade de reter elementos de seu passado africano no presente. Em comparação com Frazier, Turner estava preocupado menos com a estrutura do que com a cultura. Ele estava convencido de que a dignidade dos negros tinha de estar baseada em sua capacidade de vivenciar sua cultura e se orgulhar dela.

Comparemos agora o estilo do trabalho de campo realizado por esses três importantes estudiosos. Como vimos, Turner e Frazier trabalharam juntos. Turner tinha um gravador Edison movido a gasolina, naquela época uma raridade dispendiosa, que gravava em discos de alumínio com duração máxima de quinze minutos. Logo antes de sua viagem ao Brasil, Turner tinha feito um curso para aprender a operar essa máquina complicada. Ele tinha uma sólida formação em linguística e um interesse mais amplo em música e em como ela interage com a linguagem. Herkovits trabalhou com sua esposa, Frances, uma etnógrafa autodidata que mais tarde transcreveria seus cadernos de campo e entrevistas, e que permaneceria interessada no Brasil até o fim de sua vida. Na verdade, Frances voltou à Bahia em 1968 para prosseguir com seu trabalho de campo e, após a morte de Herskovits, tentou insistentemente, embora sem sucesso, publicar um livro com suas observaçôes sobre a Bahia. ${ }^{17}$

As redes internacionais e nacionais desses três estudiosos eram muito diferentes. Frazier apoiou-se sobre a rede tecida por seu conterrâneo de Chicago, Donald Pierson, e mais tarde por Ruth Landes, entre 1936 e 1939. Quando de sua che- 
gada, Frazier e Turner já haviam identificado uma série de contatos no seio das elites políticas assim como entre as famílias negras de classe média. Tanto Pierson como Landes tinha, construído suas redes a partir da orientação e dos contatos do jornalista e etnógrafo autodidata negro Édison Carneiro - como vimos, Landes chegou a fazer dele seu informante principal. É bem possível - embora eu não tenha encontrado evidência disso nos arquivos - que os informantes entrevistados por Frazier e Turner no mundo do candomblé, especialmente no famoso terreiro do Gantois, fossem os mesmos contatados por Landes e Carneiro. Herskovits tinha melhores contatos na elite branca desde o início, e encontrou em José Valladares um grande aliado local. Turner beneficiou-se dos contatos e da fluência em português de seu amigo e colega Frazier - um poliglota - e Frazier, por sua vez, aproveitou os métodos de gravação, as habilidades fotográficas e a companhia de Turner.

$\mathrm{O}$ estilo e o projeto político-acadêmico de Frazier podem ser discernidos em seus cadernos de campo. Para personalidades, cargos e costumes definidores do candomblé, ele utilizava os termos nativos, tais como "casa", "seita" ou "zelador". Ele parecia atribuir relativamente pouca importância às coisas africanas e, por vezes, menosprezava completamente as memórias sobre a África. Em suas entrevistas, perguntava o que as pessoas sabiam da África, que palavras africanas conheciam e se sua ascendência era africana; em seus comentários, ele consistentemente sugeria que as ações cotidianas, as estratégias de sobrevivência e os arranjos familiares eram informados muito mais pelas circunstâncias do presente do que por qualquer passado africano. Todas as anotaçōes e transcrições de entrevistas de Frazier contêm o nome e os dados básicos do informante. Ele também fotografava todos os informantes, inclusive a gente comum do "povo de santo", os seguidores do terreiro do Gantois. Cada fotografia era numerada; as pessoas retratadas eram marcadas por um número de identificação e tinham seus nomes escritos no verso - esse era o mesmo método utilizado anteriormente em sua pesquisa sobre a família negra e as igrejas negras nos Estados Unidos. Isso parece sugerir que Frazier concebia este curto mais inten- sivo trabalho de campo como um estudo piloto a ser continuado e expandido. É como se ele tivesse planos de voltar a entrevistar os mesmos informantes em algum momento.

O método de campo de Turner é radicalmente diferente do de Frazier em alguns aspectos e consideravelmente similar em outros. Ele não deixou cadernos de campo ou anotações metodológicas de fato, não há nenhuma anotação desse gênero acerca do Brasil em seus papéis na Universidade Northwestern ou no Museu da Comunidade de Anacostia. Contudo, pelas gravações, transcrições de entrevistas, anotaçôes e escritos posteriores sobre sua experiência na Bahia, sabemos que ele mostrava a seus informantes uma lista de palavras (e talvez expressōes) que tinha coletado junto aos falantes do gullah, e que reproduzia trechos gravados em fala gullah. Turner reconheceu na fala baiana diversas expressóes que ele ouvira em gullah, e agora seus informantes também reconheciam palavras nas listas escritas e nas gravaçôes. Sem questionar o fato de que muitas expressões africanas são similares em ambos os contextos - e a esse respeito as técnicas de pesquisa de Turner eram bastante avançadas e legítimas para a época -, pode-se hoje especular, observando em perspectiva, se nesse processo de reconhecimento de palavras e heranças africanas não seria necessário levar em conta a possibilidade de os informantes baianos quererem dar uma resposta socialmente satisfatória a um linguista norte-americano simpático, instruído e interessado na África.

Todas as gravaçōes de Turner e a maior parte das fotografias que tirou também têm nomes e descriçōes que facilitam o reconhecimento dos informantes. Nisso ele se aproximava do estilo de trabalho de campo de Frazier. Ambos estavam certamente interessados em fenômenos sociais e culturais, mas também estavam inclinados a nomear e humanizar seus informantes - eles viam pessoas antes e por trás desses fenômenos. Além disso, é óbvio que naqueles dias as fotografias que fizeram eram possivelmente os primeiros e únicos retratos que essas pessoas, geralmente muito pobres, tinham de si mesmas. Isso ajuda a explicar por que todos os informantes aparecem bem vestidos e arrumados nas fotografias tiradas por Frazier e Turner na Bahia. ${ }^{18}$ 


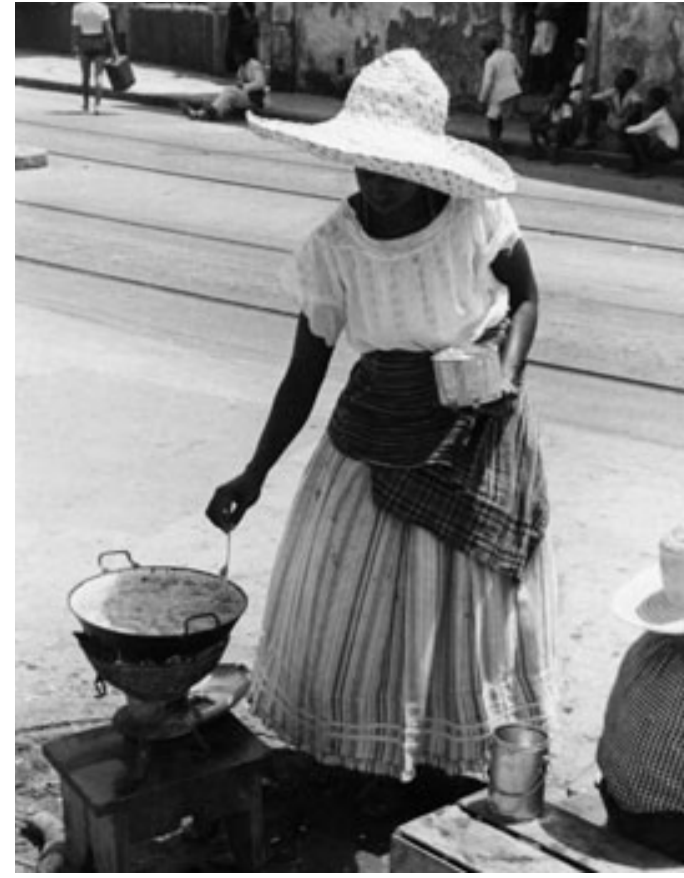

Mulher vendendo acarajé em 1941.

Fonte: Melville e Frances Herskovits Papers, Schomburg Center.

O estilo e o projeto de Herskovits se fazem notar, da mesma forma, em seus cadernos de campo e gravações musicais. Suas anotações de campo, tomadas em um caderno e mais tarde datilografadas (e possivelmente expandidas) por sua esposa Frances, somam cerca de quinhentas páginas de entrevistas e observações, catalogadas de acordo com temas. Não são mencionados nomes de informantes, exceto quando se tratava de personalidades importantes do candomblé. Ao contrário de Turner, que sempre indicava, em suas gravações musicais, o nome do compositor ou do músico, Herskovits jamais registrava informações sobre a autoria ou a execução, apenas a qual orixá aquele toque particular era dedicado. Suas gravações foram mais tarde reunidas em uma compilação e publicadas na série Folkways, do Instituto Smithsonian.

De forma similar à técnica de Turner, Herskovits apresentava a seus informantes listas de palavras em idiomas africanos, especialmente aquelas relacionadas com a religião, que ele tinha coletado durante seu trabalho de campo no Daomé (atual Benim) e ao longo da escrita de seus dois livros so-

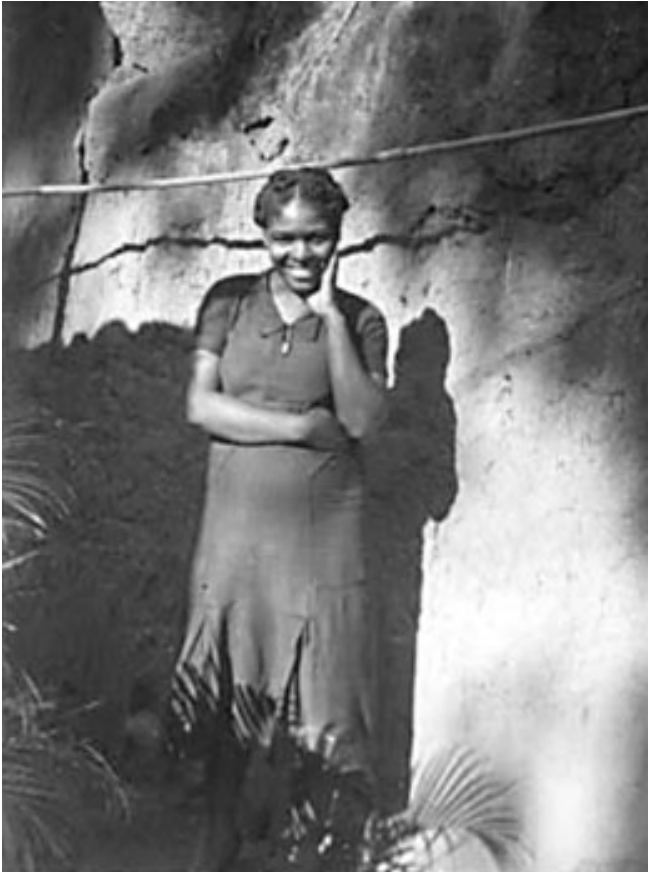

Entrevistada $n^{\circ} 30$.

Fonte: Franklin Frazier Papers, Moorland-Spingarn Documentation Center, Howard University.

bre o sistema religioso iorubá na África. Herskovits, assim como Turner e Frazier, também viera a Salvador para testar os resultados de pesquisas conduzidas em outros lugares. Nessas listas figuravam certos termos iorubás, tal como "babalorixá" para denotar as sacerdotisas do candomblé, que não eram utilizados então na Bahia, mas que passaram a ser de uso corrente entre os estudiosos daí por diante. Havia ainda outros termos utilizados que não eram (tão) nativos - "religião" em vez de "seita", "terreiro" no lugar de "casa". De muitas maneiras pode-se dizer que Herskovits abraçou a missão de descrever o candomblé como uma religião propriamente dita, e não como um culto sincrético que mesclava elementos africanos com o catolicismo popular e práticas relativas ao mau-olhado, como era geralmente retratado pela imprensa local. Ao fazê-lo, Herskovits alargou e tornou mais sofisticada a pesquisa levada a cabo pelos estudiosos brasileiros Arthur Ramos e Édison Carneiro, de cujos trabalhos ele estava muito bem ao corrente.

Assim como Turner, Herskovits tentava, em suas entrevistas, despertar memórias africanas, as- 
sim como encontrar africanismos. É preciso ter em mente que a década de 1930 havia assistido aos primeiros passos da antropologia brasileira. Havia sido também um período de incorporação simbólica das origens africanas de grande parte da cultura e da religião populares na representação cultural oficial da nação pelo ditador populista Getúlio Vargas (Williams, 2001; Sansone, 2004). Esse processo, nem é preciso dizer, fez do Brasil um lugar ainda mais interessante para se visitar, e da população afro-brasileira um objeto ainda mais interessante de pesquisa.

Os três pesquisadores entrevistaram basicamente o mesmo núcleo de pessoas em torno do terreiro do Gantois. Frazier identificava seus informantes, tal como Turner. Frazier entrevistou ainda aproximadamente quarenta pessoas, a maioria mulheres, que viviam próximo ao Gantois, e vinte integrantes da chamada "elite negra" (médicos, advogados e comerciantes).

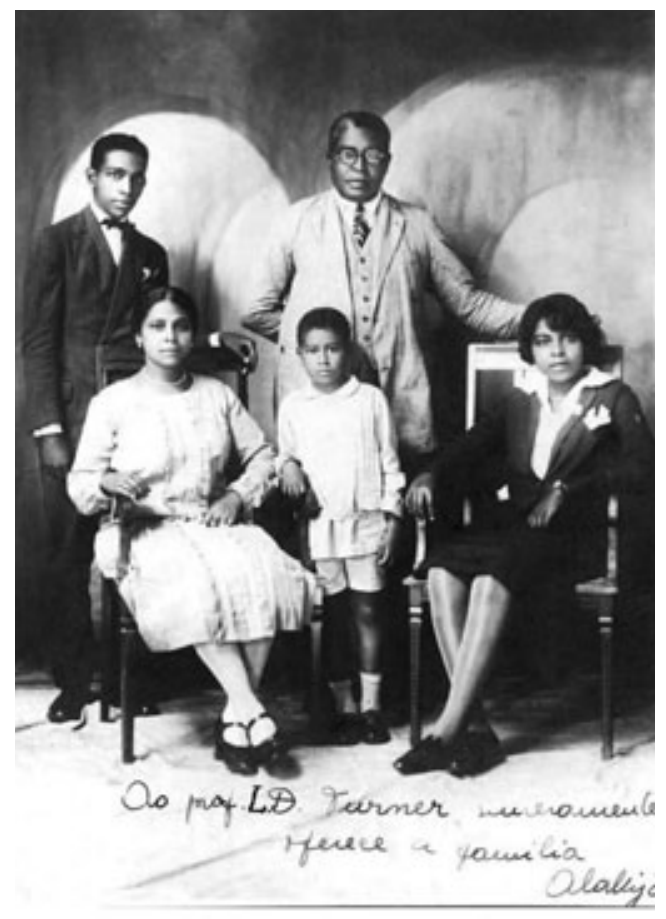

Porfírio Maxmiliano (Maxwell) Alakija (Assumpção) e familia na Bahia. A família Assumpção/Alakija era dividida entre Salvador e Lagos (Nigeria).

Fonte: Lorenzo Dow Turner Papers, Anacostia Community Museum Archives, Smithsonian Institution.
Turner, por sua vez, entrevistou uma série de pessoas-chave de famílias negras abastadas que tinham parentes na Nigéria ou em Daomé. Turner conseguiu a aceitação por parte dessas famílias, e pode-se imaginar que foi por conta disso que ele obteve cópias e o original de um passaporte de negros baianos retornando à África, assim como fotografias dessas famílias, na Bahia e em Lagos. ${ }^{19}$

Herskovits concentrou sua pesquisa nas mães de santo, em seus seguidores imediatos (filhas da casa e assistentes religiosos) e nas personagens masculinas dos ogãs. Em resumo, Herskovits, na linha de Ramos e Carneiro, concentrou-se na religião, enquanto Turner e Frazier se concentraram na comunidade em torno do terreiro de candomblé.

Vale a pena mencionar que a elite negra foi o tema da pesquisa realizada posteriormente pelo antropólogo baiano Thales de Azevedo, com patrocínio da Universidade Colúmbia e da Unesco (Azevedo, 1996 e 2008). Minha impressão é de que Azevedo baseou sua pesquisa nas famílias negras que haviam sido contatadas por Pierson (e possivelmente por Landes) e mais tarde fotografadas e entrevistadas por Frazier e Turner. Estes, no entanto, identificaram seus contatos em cadernos de campo, entrevistas e fotografias. Em seus livros, nem Pierson nem Azevedo, que também publicou uma série de fotografias de famílias negras de classe média, mencionaram seus nomes.

Há um punhado de outras diferenças a respeito do relacionamento entre esses três estudiosos e seus informantes e temas de pesquisa. Herskovits pagava por suas entrevistas, e manteve uma lista cuidadosa de todos os seus pagamentos desde o momento em que deixou Nova York até o momento em que retornou. Como demonstra o livro The root of roots ("A raiz das raízes"), de Richard e Sally Price (2003), que trata da viagem de campo do casal Herskovits ao Suriname no ano imediatamente anterior ao de sua visita ao Brasil, essa não era uma prática incomum em seu trabalho de campo. Além disso, eles mantiveram contato não somente com diversos antropólogos e sociólogos brasileiros, mas também com alguns de seus principais informantes baianos ao longo dos anos. Os papéis de Herskovits no Centro Schomburg contêm uma série de cartas de sacerdotisas do candomblé solicitando doações 
financeiras para seus terreiros. Também Turner pagou certa quantidade de dinheiro a seus informantes. Até onde sei, Frazier não pagou a seus entrevistados. Nas cartas de Frazier e Turner não encontrei nenhum pedido de apoio por parte do povo de santo, nem correspondência com colegas brasileiros após a volta para os Estados Unidos.

Outra diferença é que nem Turner nem Frazier, ainda que bastante interessados e atentos à hierarquia, à disciplina e à missão do terreiro do Gantois, jamais assumiram a posição formal de ogã ou obá de Xangô - que foi concedida a Herskovits e a outros estudiosos que pesquisaram o Gantois ou outros terreiros de prestígio (como Nina Rodrigues e Arthur Ramos nos primeiros anos, ou Roger Bastide, Alfred Métraux e Pierre Verger, mais tarde), assim como a políticos e a artistas famosos, como Jorge Amado. Por outro lado, não há evidência concreta de que a raça tenha significado maiores impedimentos ao trabalho de campo de Turner e Frazier; ao contrário, a partir de sua correspondência pode-se perceber que eles se divertiram um tanto e aproveitaram a liberdade de se mover através de diversos ambientes sociais. Vejo duas possibilidades para explicar o fato de eles dois não terem sido agraciados com essa posição honorária. É possível que, devido à política e à discriminação raciais prevalecentes à época, estrangeiros negros, mesmo que cidadãos norte-americanos e acadêmicos reconhecidos, não fossem facilmente convidados a assumir posições honorárias em casas de candomblé. Outra possibilidade é a de que Turner e Frazier, por serem negros, não precisassem assumir tais posições formais para serem aceitos na comunidade do terreiro.

Por fim, os três pesquisadores diferiam na forma como fotografavam. Quando se compara a composição das fotografias, percebe-se que Herskovits não é jamais retratado próximo a seus informantes. Quando há um retrato dele na Bahia, ele está próximo de sua família, colegas antropólogos ou José Valladares - seu contato principal. Herskovits, além disso, fez muito mais fotografias de objetos, tais como oferendas aos deuses, árvores sagradas, esculturas de orixás e instrumentos musicais. Ele fotografou muito poucas pessoas além daquelas dentro da comunidade do terreiro. Frazier

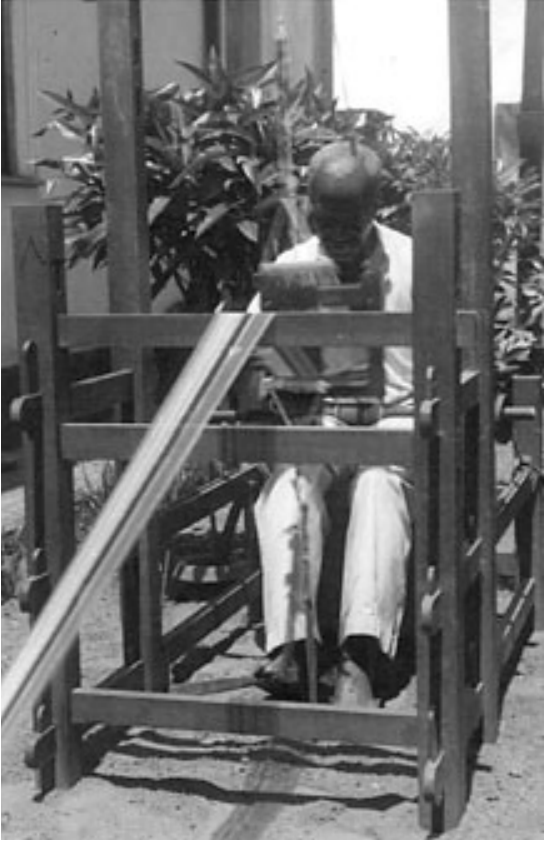

O último tecelão de pano da costa do qual se tem notícia - uma tradição interrompida que foi retomada recentemente.

Fonte: Lorenzo Dow Turner Papers, Anacostia

Community Museum Archives, Smithsonian Institution.

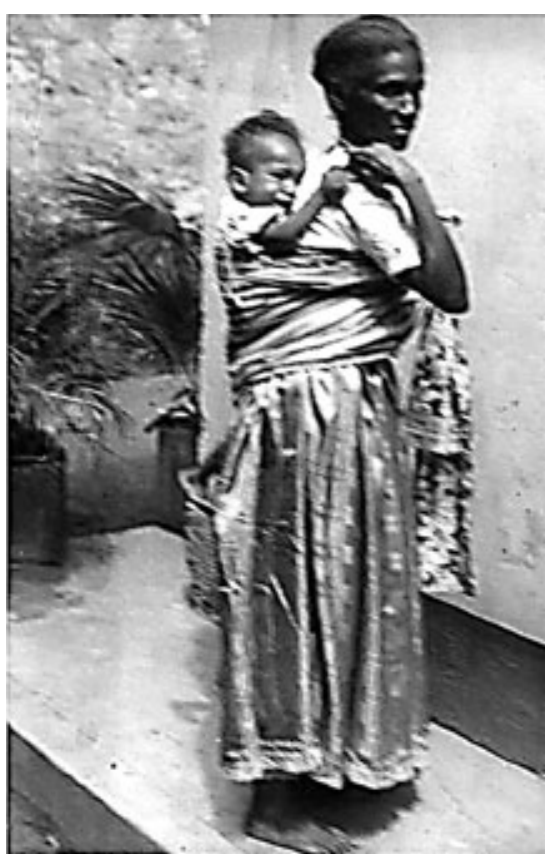

Mulher carregando filho nas costas.

Fonte: Lorenzo Dow Turner Photographic Collection, Anacostia Museum, Smithsonian Institute. 


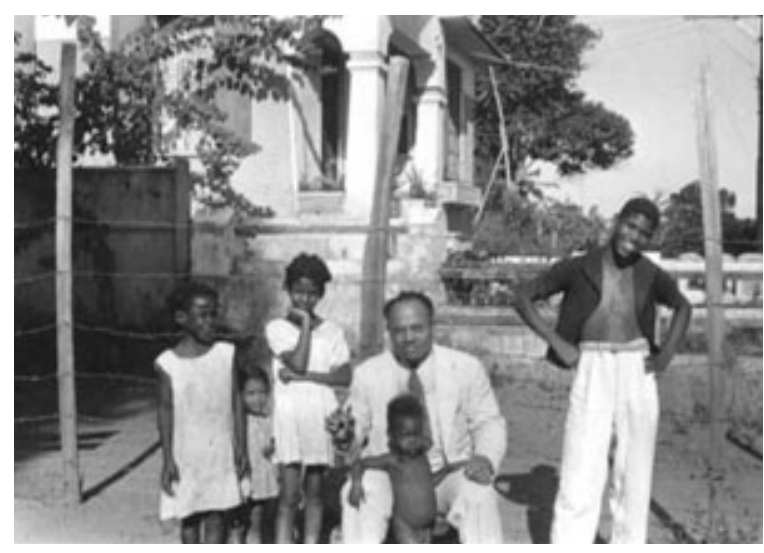

Franklin Frazier com os filhos de mulheres entrevistadas no Gantois.

Fonte: Franklin Frazier Papers, Moorland-Spingarn Documentation Center, Howard University.

foi fotografado duas vezes junto a seus informantes, uma das quais segurando a mão de uma criança pequena. Turner fazia fotografias de afro-brasileiros comuns, não apenas de seus informantes, e acrescentava uma pequena descrição, geralmente se referindo à capacidade da pessoa retratada de falar iorubá ou outro idioma africano.

Eles diferiam ainda em termos de sua agenda antirracista. Turner e Frazier não eram apenas pesquisadores negros com uma agenda antirracista; estavam também interessados em entrar em contato com negros importantes, com a elite negra. Herskovits tinha também uma agenda antirracista própria, mas estava muito menos interessado no protagonismo negro, e ainda menos na elite negra (Gershenhorn, 2004). Pode-se imaginar que ele preferia "autenticidade" nos africanismos, e não pessoas que se comportavam, em muitos aspectos, como intelectuais brancos ou como a classe alta branca faria.

Por trás dessas diferentes abordagens em seus métodos havia posições divergentes a respeito da herança africana de seus objetos de pesquisa. Turner e Herskovits estavam convencidos de que o passado africano oferecia o tipo de grandeza cultural que eles viam como necessário para a luta dos negros por liberdade nos Estados Unidos. Frazier não estava convencido em absoluto de que o passado era um aliado potencial para a libertação dos negros, em uma posição surpreendentemente reminiscente da interpretação de Frantz Fanon do passado como grilhões com os quais os oprimidos tinham de acertar as contas por meio de uma ruptura simbolicamente violenta (Guimarães, 2008). Frazier estava muito mais interessado no futuro, no lugar da negritude no seio da modernidade. Essa atitude era em grande medida uma tomada de posição política contra o que Frazier percebia como as generalizações estereotipadas da reconstrução de uma grandeza negra baseada no passado. ${ }^{20}$

Nesse contexto, Herskovits estava em vantagem. Ele tinha passado mais tempo em campo, e sua abordagem sobre a cultura africana no Brasil encaixava-se bem com o esforço renovado de diversos intelectuais brasileiros para redefinir a cultura popular nacional. Além disso, ele tinha melhores e mais poderosas conexôes com a emergente comunidade antropológica brasileira, tanto na Bahia como no Museu Nacional no Rio de Janeiro (naqueles dias, o centro nacional absoluto da antropologia brasileira). Herskovits tinha ainda melhor acesso a financiamentos para pesquisas e estava em uma posição mais propícia para convidar pesquisadores brasileiros para visitar os Estados Unidos. ${ }^{21}$

Como sabemos, Herskovits deixou sua marca na antropologia das expressões culturais afro-americanas. Ele também atraía a atenção da academia no Brasil, tanto que em maio de 1943 foi convidado a ministrar a aula magna da Faculdade de Filosofia da Bahia (atualmente a Faculdade de Filosofia e Ciências Humanas da Universidade Federal da Bahia). ${ }^{22}$ Ele apelava ainda para o cânone da antropologia da época, especialmente os temas românticos da Escola da Cultura e da Personalidade e sua paixão por grupos e formas culturais apolíneos. Isso se encaixava com perfeição à reivindicação iorubá de singularidade, pureza e autenticidade na religião.

Ainda que inicialmente tenha planejado reencontrar seus informantes do Gantois, Herskovits nunca chegou a fazê-lo. Em 1954, veio ao Brasil para participar do Congresso Internacional Latino-americano. Sua filha Jean, que esteve com seus pais na Bahia quando era uma criança, e depois se tornou uma africanista, contou-me que ele de fato foi à Bahia nessa ocasião, mas não visitou o terreiro de candomblé que fora tão importante 
para seu trabalho de campo e que se tornara importante também para sua vida pessoal. De acordo com Jean, Herskovits era bastante supersticioso e sempre se impressionava com o poder mágico e divinatório do candomblé. ela me contou que seus pais estavam convencidos de que suas vidas haviam sido salvas pelo candomblé. Quando chegou a hora de voltar aos Estados Unidos, o casal Herskovits foi convencido a não embarcar no navio (eles terminaram voltando de avião) por um grupo de sacerdotisas que lhes deu um machado de Xangô esculpido em madeira, para proteção. $\mathrm{O}$ navio em que teriam viajado, o SS Bill, foi de fato afundado por um submarino alemão, e com isso foi perdida uma cópia das gravações e dos cadernos de campo, além de todos os objetos afro-brasileiros que o casal havia adquirido no Brasil para o museu da Universidade Northwestern (Herskovits Papers, cx. 4, mç. 12). Felizmente Herskovits havia deixado uma cópia desse material no consulado norte-americano em Salvador, e tinha enviado uma segunda cópia, por correio, para os Estados Unidos. Como pude ver pessoalmente, esse machado de madeira é hoje um objeto venerado na casa de Jean Herskovits em Nova York, uma lembrança doce-amarga da Bahia, do candomblé e de seus pais.

Entre 1941 e 1943, Frazier publicou seis artigos sobre relações raciais no Brasil e a família negra na Bahia (ver Bibliografia). O Brasil tornou-se uma peça central em seu argumento tanto sobre a família negra como sobre o fato de a raça ser o verdadeiro dilema norte-americano. Esses foram os anos que levaram à preparação do livro histórico de Gunnar Myrdal, The American dilemma, publicado em $1941 .{ }^{23}$ Frazier participou dessa iniciativa, mas em que extensão o fez tem sido motivo de recente discussão. A produção de Frazier sobre o Brasil, entretanto, não marcou a história das ciências sociais de forma tão poderosa quanto a de Herskovits. Mesmo em biografias recentes deste grande sociólogo, que gostava de se definir como um "homem da raça", há pouca ou nenhuma menção a seu trabalho sobre o Brasil ou sobre o Caribe. Ele é geralmente descrito como alguém mais nacional do que Herskovits. Acredito que Frazier era um pesquisador cosmopolita, poliglota e orientado para a arena internacional, que, de diversas manei- ras, quis fazer o mesmo tipo de trabalho com grandes comparações internacionais que Herskovits havia desenvolvido. Frazier não conseguiu se tornar uma influência duradoura nas ciências sociais brasileiras, embora ele certamente tenha dialogado com a política cultural da Frente Negra - grupo que, na década de 1930, representava a vanguarda do pensamento negro brasileiro, e ressaltando a universalidade da condição humana mais do que as diferenças culturais, e reivindicando um lugar de destaque para os negros no seio da modernidade (Platt, 1990, 1991, 1996; Teele, 2002).

Em resumo, como pode ser depreendido de suas anotaçōes no Centro Moorland-Spingarn na Universidade Howard, da década de 1940 até o fim de sua vida Frazier se ressentiu profundamente de todos os obstáculos que ele experimentou e que o impediram de se tornar o acadêmico universal que ele certamente ansiava ser (Frazier Papers, cx. 131133). Ele permaneceu sintonizado com a corrente principal da sociologia por toda a sua vida, e foi o primeiro presidente negro da Associação Sociológica Americana em 1948 (os pareceristas de sua candidatura à bolsa de estudos da Fundação Guggenheim para sua viagem ao Brasil eram ninguém menos que os três nomes principais da escola de estudos socioantropológicos urbanos da Universidade de Chicago, Ernest Burgess, Robert Park e Luis Wirth). Não obstante, ele permaneceu insatisfeito com o lugar dos intelectuais negros norte-americanos no mundo acadêmico e também com a mediocridade e com a autocomplacência dos intelectuais que operavam exclusivamente no âmbito da comunidade negra. ${ }^{24}$ Frazier jamais retornou ao Brasil.

Turner, como demonstram seus papéis na $\mathrm{Bi}$ blioteca de Estudos Africanos Melville J. Herskovits da Universidade Northwestern e segundo entrevistas concedidas a mim por seu filho e sua esposa, utilizou gravações, entrevistas, impressões e mesmo um conjunto de objetos adquiridos na Bahia (instrumentos musicais, estátuas de orixás e adornos do candomblé) em suas aulas e conferências em universidades, escolas secundárias e organizações comunitárias. Em conjunto com suas descobertas linguísticas sobre o gullah e, mais tarde, sobre o crioulo de Serra Leoa, suas observações baianas corroboraram sua compreensão da centralidade da 
África na fala negra contemporânea. Ele via seu trabalho como intrinsecamente transnacional e transatlântico, mas isso mal chegou a ser reconhecido pelo establishment acadêmico. ${ }^{25}$ Turner também nunca voltou ao Brasil. ${ }^{26}$

Apesar dessas marcantes diferenças, esses três pesquisadores também apresentavam similaridades significativas. Todos eles utilizaram suas experiências e descobertas na Bahia, e, de modo mais geral, no Brasil, como trampolins para a construção do campo de Estudos Africanos nos Estados Unidos. Turner e Frazier tiveram um papel central e pioneiro na fundação de departamentos de Estudos Africanos nas universidades Fisk (Turner, em 1943) e Howard (Frazier, em meados da década de 1940). Herskovits fundou o primeiro departamento interdisciplinar de Estudos Africanos na Universidade Northwestern em 1948 (Gersenhorn, 2004, p. 169). Ainda que o programa criado por Herskovits tenha crescido e em pouco tempo se tornado o mais importante dos Estados Unidos (não é à toa que a biblioteca especializada em Estudos Africanos na Universidade Northwestern leva seu nome), não se pode menosprezar o papel pioneiro das universidades Fisk e Howard na conformação do campo dos Estudos Africanos, e na atração de pesquisadores africanos para os Estados Unidos. Esse fator foi, e ainda é, especialmente importante na internacionalização das universidades negras tradicionais norte-americanas.

Ademais, Turner, Frazier e Herskovits vieram à Bahia testar os resultados de pesquisas conduzidas em outros locais, assim como para corroborar hipóteses sobre a origem africana da cultura negra. $\mathrm{O}$ terreiro do Gantois representou o estudo de caso compartilhado e, ao fim e ao cabo, eles entrevistaram as mesmas pessoas. E, como é o caso, os três encontraram no Gantois a explicação que estavam procurando - respectivamente, a escravidão e a adaptação à pobreza (Frazier) e os africanismos (Turner para a linguagem e Herskovits para a estrutura familiar). Eles têm em comum ainda o fato de que nenhum deles fez do Brasil e da Bahia a pedra fundamental de seus estudos, como tinham proposto ao se candidatar às bolsas para suas pesquisas aqui. Nenhum dos três jamais escreveu o livro sobre a Bahia que tinha planejado.
A Bahia foi para eles o estudo de caso de uma hipótese gerada no contexto político, moral e racial norte-americano. $\mathrm{O}$ fato é que a fala negra e a estrutura familiar negra eram preocupações norte-americanas, não brasileiras. Então, como agora, eruditos e leigos concordam em que não existe algo como um "português negro", mas, de fato, o uso de uma linguagem normalmente definida como iorubá nas cerimônias de candomblé e uma pletora de termos de origem banto no português falado no Brasil. A respeito da "família negra", o termo permanece não sendo utilizado no Brasil, onde a matrifocalidade é associada quer com a pobreza, quer com modos de vida, e não com africanismos - uma importante exceção é Marcelin (1999).

Suas pesquisas de então diziam respeito a uma batalha norte-americana travada em solo brasileiro, e que nunca fez seu caminho de volta ao Brasil. Na verdade, informações sobre seu trabalho foram de alguma forma repatriadas por mim, um antropólogo italiano branco. Isto é, muito poucos de meus colegas na Bahia conheciam os dois famosos artigos de Frazier e Herskovits na American Sociological Review até eu deixar uma fotocópia de cada um na biblioteca da Universidade Federal da Bahia, em 1992. Contudo, esses textos foram importantes para diversos debates sobre a família negra nos Estados Unidos nos anos de 1970, e são importantes ainda hoje para a releitura crítica de etnografias clássicas da época, tal como a de Ruth Landes (Fry, 2002).

As gravações e as fotografias de Turner, apesar de seu excepcional valor, permaneceram invisíveis e desconhecidas para a vasta maioria dos acadêmicos brasileiros até há bem pouco tempo. A recente repatriação digital de cópias de suas fotografias e gravaçôes para o terreiro do Gantois em sessōes organizadas pelo Museu Digital da Memória Africana e Afro-Brasileira - permitiu aos mais velhos reconhecerem a maior parte dos informantes de Turner. Eles ficaram comovidos com a oportunidade de ouvir as vozes de pessoas tão importantes para a comunidade do candomblé e deram enorme valor às gravaçôes das vozes de lideranças religiosas de outros tempos. Este projeto tenciona dar uma nova relevância ao trabalho de Turner na Bahia. ${ }^{27}$ 
Desde os seus primeiros passos nos anos de 1930 os Estudos Afro-brasileiros, especialmente no que se refere à antropologia, era um campo de estudos transnacional, tenso e denso, entrelaçado com agendas culturais, raciais e políticas seguidamente originadas nos Estados Unidos ou na França. A dimensão internacional, e mesmo transnacional, dos Estudos Afro-brasileiros, desde a sua inserção no establishment acadêmico em meados da década de 1930 até hoje, demonstra ser necessária uma apreciação crítica sobre o poder e a posição do conhecimento no intercâmbio acadêmico entre Brasil e Estados Unidos. Isso pode levar a descobertas muitas vezes dolorosas a respeito das relações complexas e desiguais entre contatos locais (ou guardiões), tais como Édison Carneiro e José Valladares, e professores universitários norte-americanos em visita à Bahia. Aqueles detinham o conhecimento local, enquanto estes, especialmente se eram brancos, tinham para oferecer bolsas ou conexões com universidades norte-americanas. Dá para imaginar de que maneira a reunião de informaçôes e a imagem feita do Brasil por esses informantes-chave foi afetada pela base desigual dessa troca intelectual. Parece que a maior parte desses informantes de então, e talvez ainda hoje, tende a contar aos visitantes norte-americanos exatamente o que eles desejariam saber e "descobrir". Naquela época, para enfrentar a segregação racial nos Estados Unidos, eles procuravam no Brasil uma democracia racial, e lhes foram apresentadas "evidências" dela. Na década de 1990, pesquisadores norte-americanos tendiam a retratar o Brasil como um show de horrores (a modernidade falhada), e receberam "evidências" de que o Brasil era, na verdade, um inferno racial. ${ }^{28}$ Com o advento do governo Lula as coisas mudaram mais uma vez, e o Brasil voltou novamente a ser representado como um exemplo positivo para a luta contra as desigualdades raciais. Uma perspectiva refinada e comparativa das relações raciais no Brasil e nos Estados Unidos, concentrada nas similaridades bem como nas particularidades locais ou nacionais, e uma relação mais horizontal e equilibrada entre acadêmicos baseados nos Estados Unidos e no Brasil nesse campo ainda estão, ambas, por serem desenvolvidas.

\section{Notas}

1 Este artigo é baseado em pesquisa nos arquivos que abrigam os documentos de três extraordinários intelectuais, rivais, e contudo amigos: Melville Herskovits, E. Franklin Frazier e Lorenzo Dow Turner. Os arquivos consultados foram: os Arquivos da Universidade da Northwestern University, em Evanston, Illinois, o Centro Schomburg para a Pesquisa sobre a Cultura Negra, em Nova York, e o Museu Nacional de Arte Africana do Instituto Smithsonian, em Washington D.C., para Herskovits; o Centro de Pesquisa Moorland-Spingarn da Universidade Howard, em Washington D.C., para Frazier; e o Museu da Comunidade de Anacostia e a Biblioteca Melville Herskovits de Estudos Africanos da Northwestern University, para Turner. Este texto utiliza ainda pesquisa realizada no Museu da Ciência, no Fundo Artur Ramos da Biblioteca Nacional e nos Arquivos do Museu Nacional, no Rio de Janeiro, além de buscar uma leitura cuidadosa de notas de rodapé, introduções, resenhas de livros e agradecimentos relacionados com tudo o que fosse brasileiro nas obras desses três estudiosos. Sou devedor de um razoável número de excepcionais especialistas que generosamente dividiram comigo seus dados e intuiçôes: Kevin Yelvington, David Hellwig, Sally Cole, Anthony Platt e Pol Briand. Agradeço especialmente a David Easterbrook, da Biblioteca Melville Herskovits de Estudos Africanos; a Eleen Elbashir do Centro de Pesquisa Moorland-Spingarn; a Amy Staples, curadora dos arquivos do Museu Nacional de Arte Africana; a Portia James, curadora do Museu da Comunidade de Anacostia; a Dr. Leopold, do Arquivo Nacional de Antropologia do Instituto Smithsonian; e à professora Jean Herskovits. Agradeço ainda a Scott French, do Instituto Carter-Woodson Institute da Universidade da Virgínia, por sua ajuda sobre história digital e arquivos. Um agradecimento especial é dedicado a Alcione Amos do Museu da Comunidade de Anacostia, sem a qual este trabalho jamais teria sido escrito. Agradeço também os colegas Marcos Chor Maio, Peter Fry, Antonio Sergio Guimarães, Mariza Correa e Claudio Pereira pelas inúmeras sugestões e ideias que me proporcionaram em torno destes temas ao longo dos anos. Uma versão mais curta deste artigo será publicada no periódico estadunidense Black Scholar. A pesquisa, que se extendeu de 2005 a 2011, recebeu o apoio da Prince Claus Foundation, do CNPq e da Finep. Fabio Baqueiro traduziu o texto com o talento que lhe é tradicional, acrescentando interessantes sugestôes. 
2 A Declaração sobre raça da Unesco está disponível em <http://www.unesco.org>, tendo sido publicada originalmente na revista inglesa Man, 50: 139-139, 1950.

3 Ver, em primeiro lugar, os trabalhos de Marcos Chor Maio (1997, 1999, 2000, 2001 e 2011) e de Antônio Sérgio Guimarães (2007 e 2008); para uma coletânea de artigos que também inclui esses dois autores, ver Pereira e Sansone (2007).

4 Minha pesquisa atual enfoca os projetos da Unesco na Bahia e, de modo mais abrangente, no Brasil. Trata-se de uma reavaliação crítica daquele empreendimento intelectual e um retorno ao campo. Para esse projeto, realizei pesquisa em numerosos arquivos e efetivamente retornei ao campo, tendo feito trabalho de campo na região da mesma usina de açúcar onde William Hutchinson fez a pesquisa para sua tese de doutorado, entre 1950 e 1953, sob a orientação de Charles Wagley (Sansone, 2007).

5 Estados Unidos, University of Massachusetts, W. E. $\mathrm{Du}$ Bois Library, Special Collections and University Archives, W. E. Du Bois Papers, 1868-1963.

6 Para uma descrição da visita que Park fez a Pierson na Bahia, ver Valladares (2010).

7 Naquele período, caracterizado pelo regime autoritário do Estado Novo de Getúlio Vargas (1937-1945), pesquisadores estrangeiros no Brasil necessitavam de uma autorização concedida pelo então extremamente repressivo Ministério da Justiça. Essa autorização com frequência era feita em colaboração com a Diretoria do Museu Nacional. Há evidências, nos arquivos do museu, de que Lorenzo, Franklin e Mel (como eram chamados pelos amigos) obtiveram tal permissão. Acadêmicos estrangeiros assinavam ainda um documento por meio do qual se comprometiam a enviar ao Museu Nacional uma cópia do livro ou relatório resultante de sua pesquisa no Brasil - o que, muitas vezes, terminava por não ocorrer. Dos três pesquisadores tratados neste artigo, apenas Herskovits enviou um relatório, apesar das cartas que a Diretora do Museu Nacional enviou aos outros dois para lembrá-los deste compromisso. Nenhum dos três, entretanto, chegou a publicar o livro sobre o Brasil que estavam obrigados a escrever de acordo com seus projetos de financiamento de pesquisa.

8 Esses artigos podem ser consultados no Centro de Pesquisa Moorland-Spingarn e no Museu Digital da Memória Africana e Afro-Brasileira (<http://www. museuafrodigital.ufba.br>). Ali podem ser consultadas uma série de coleções, dentre as quais as mais relevantes para este texto são as de Lorenzo Dow Turner, E. Franklin Frazier, Melville Herskovits, Donald Pierson e Ruth Landes. Este Museu Digital comporta estações na Bahia, Rio de Janeiro, Maranhão e Pernambuco, coordenadas, respectivamente, por Livio Sansone (UFBA), Myrian Santos (UERJ), Sérgio Ferretti (UFMA) e Antonio Motta (UFPE).

9 Ver mais sobre a história da "política de boa vizinhança" em <http://www.u-s-history.com/pages/h1646.html>.

10 Uma entrevista com Orson Welles e trechos do documentário estão disponíveis em <http://canhotagem. blogspot.com>.

11 Maiores informações em <http://en.wikipedia.org/ wiki/It's_All_True_(film)>, acessado em 24/2/2011.

12 A animação está disponível em <http://www.youtube.com/watch? $\mathrm{v}=\mathrm{JSBxY}$ cxnhf8 $>$, acessado em $24 / 2 / 2011$.

13 Moorland-Spingarn Research Center, E. Franklin Frazier Papers (doravante citado como Frazier Papers), cx. 131, mç. 133-137.

14 Como parte de um projeto colaborativo entre a Melville Herskovits Library da Northwestern University e o Museu Digital da Memória Africana e Afro-Brasileira, este manuscrito será disponibilizado on line num futuro próximo.

15 University Archives, Melville e Frances Herskovits Papers (doravante citado como Herskovits Papers), cx. 36, mç. 2.

16 De Valladares, ver, entre outros, Bêe-a-bá da Bahia, de 1956 e Museus para o povo, de 1944.

17 Como pode ser depreendido da correspondência e dos recortes de jornais no arquivo do Schomburg Center (Melville \& Frances Herskovits Papers, box 55, folders 585 a 590) em sua segunda visita à Bahia, Frances Herskovits procurou e recebeu o apoio do Centro de Estudos Afro-orientais da UFBA, onde se reuniu com Thales de Azevedo, Valdir Freitas Oliveira, Vivaldo da Costa Lima e o "jovem e brilhante antropólogo" Julio Braga. Os últimos dois acompanharam-na e aconselharam-na nas visitas às casas de santos e a alguns dos antigos informantes da pesquisa de 1941-1942 (ver também artigo no quotidiano $A$ Tarde de 28/1/1967). Nos anos sucessivos, Frances Herskovits tentou, mas não conseguiu, publicar o manuscrito em que reuniu o material coletado por ela e Melville em 1941-1942 com o material resultado da curta mas intensa volta ao campo em 1967.

18 Para compreender a importância dessas fotografias é preciso lembrar que, até bem pouco tempo atrás, para 
a maior parte dos brasileiros pobres, "tirar retrato" era um evento social importante - a maioria era fotografada, durante toda a sua vida, apenas uma ou duas vezes: uma em seu próprio casamento e outra, no caso dos homens, para a carteira de trabalho. As fotografias originais feitas por Turner encontram-se no Museu da Comunidade de Anacostia, em Washington D.C. A maior parte das fotografias tiradas por Turner, Frazier e Herskovits na Bahia pode ser vista no Museu Digital da Memória Africana e Brasileira.

19 Para mais informações sobre os afro-brasileiros que retornaram para a África Ocidental no século XIX, ver $A$ mos (2007).

20 Turner e Frazier mantiveram-se fiéis a suas posiçôes divergentes em relação aos possíveis africanismos na cultura negra norte-americana, e ainda assim interessados no futuro da África pós-independência pelo resto de suas vidas. Ambos contribuíram para uma edição especial da revista Présence Africaine, editada em formato de livro e dedicada ao tema da relação entre os negros norte-americanos e a África (Frazier, 1962; Turner, 1958).

21 A falta de financiamento limitou os planos tanto de Turner como de Frazier para pesquisar na África e para desenvolver os Estudos Africanos em suas respectivas universidades (Universidade Fisk, e mais tarde Universidade Roosevelt, no caso de Turner, e Universidade Howard, no caso de Frazier). Enquanto Herskovits podia dispor do auxílio de um conjunto de estudantes de doutorado, Turner tinha de se basear em informantes africanos que viviam nos Estados Unidos e teve menos oportunidades para fazer pesquisa na África. Turner foi finalmente à África em 1951, por intermédio de uma bolsa da Fundação Fullbright, e mais tarde trabalhou sobre a língua crioula krio da Serra Leoa com bolsas da agência Corpos da Paz. Frazier teve de esperar até o momento em que passou um ano na Unesco em Paris, a convite de Alfred Métraux, no fim da década de 1950, para poder trabalhar com africanistas e com pesquisadores africanos na organização da primeira conferência sobre industrialização na África - um tema afim a seu interesse pelo lugar do negro e do africano na modernidade.

22 O texto dessa conferência encontra-se em Herskovits (1966) e foi traduzido por José Valladares. Também foi apresentado como relatório final de pesquisa ao Museu Nacional no Rio de Janeiro, e foi publicado pela primeira vez no Brasil em 1944, pelo Museu de Arte da Bahia, com um prefácio de Isaías Alves, o primeiro diretor da Faculdade de Filosofia da Bahia. A revista Afro-Ásia publicou-o novamente em 1967, e o Museu de Arte da Bahia publicou-o uma terceira vez em 2008. Por outro lado, não há traduçōes para o português disponíveis para os artigos escritos por Turner e Frazier. Obviamente pode-se especular acerca dos efeitos dessa política de tradução sobre a hegemonia do paradigma de Herskovits nos Estudos Afro-brasileiros e nos Estudos Afro-latinos em geral (Yelvington, 2006). Esse paradigma foi reforçado por um conjunto de pesquisadores de renome que seguiram essa trilha, tais como os conhecidos estudiosos franceses Pierre Verger e Roger Bastide.

23 Em 1935, em pleno New Deal, a fundação filantrópica Carnagie Corporation planejou uma grande pesquisa sobre a condição do negro nos Estados Unidos que acabou sendo coordenada pelo economista sueco Gunnar Myrdal. A pesquisa resultou na publicação de um detalhado relatório em dois volumes em formato de livro, cujo título ficou famoso na história das ciências sociais, Um dilema americano. A obra tinha como objeto mapear o estatuto da população negra em diversas frentes e apontar pelo grande dilema dos Estados Unidos: como um país pode ser democrático e, ao mesmo tempo, segregar a parcela negra de sua população? Para a coordenação da pesquisa chegaram a ser cogitados também Melville Herskovits e Alfred Metraux, mas se preferiu Myrdal por ele ser estrangeiro e com mais experiência política, como assessor de diversos programas sociais do governo social-democrata da Suécia. Sobre este projeto e seu contexto a melhor referencia é, sem duvida, Jackson (1994).

24 Ver o manuscrito inacabado The negro intellectual ("O intelectual negro"), em Frazier Papers, cx. 131.

25 Olivia Gomes da Cunha foi possivelmente a primeira brasileira a assinalar a importância do trabalho de Turner sobre o Brasil (Gomes, 2005, pp. 7-32). Pol Briand, um pesquisador independente francês, também tem-se dedicado recentemente a destacar essa produção.

26 Os cadernos de campo propriamente ditos de Turner não foram encontrados nas duas coleções que reúnem seus documentos, na Biblioteca de Estudos Africanos Melville Herskovits da Universidade Northwestern e do Museu da Comunidade de Anacostia do Instituto Smithsoniano. Essa é, obviamente, uma grande perda e um obstáculo para a reconstrução da experiência de Turner no Brasil.

27 O processo de repatriação digital recebeu o apoio dos Arquivos de Música Tradicional da Universidade de Indiana em Bloomington, onde a coleção das gravaçōes de Turner está custodiada; da Biblioteca de 
Estudos Africanos Melville J. Herskovits da Universidade Northwestern; e especialmente do Museu da Comunidade de Anacostia do Instituto Smithsonian, que abriga a maior parte das fotografias e dos objetos coletados por Turner em sua pesquisa.

$28 \mathrm{Na}$ verdade, pode-se argumentar que os estudos étnicos e raciais sempre foram um campo científico tão transnacional quanto tenso, em que pese a alegação de Pierre Bourdieu e Loïc Wacquant (2002) de que isso resulta de uma mais recente internacionalização ou mesmo de uma americanização - dos cânones acadêmicos. O debate suscitado pelo famoso artigo de Bourdieu e Wacquant precisa ser historicizado e tem raízes históricas muito mais profundas do que usualmente se pensa, chegando até a própria conformação da nação brasileira. Ver as edições especiais dos periódicos Theory, Culture and Society (2003) e Estudos Afro-asiáticos (2002).

\section{BIBLIOGRAFIA}

AMOS, Alcione M. (2007), Os que voltaram: a história dos afro-brasileiros que voltaram para a Africa no século XIX. Belo Horizonte, Tradição Planalto.

AZEVEDO, Thales de. (1996), As elites de cor numa cidade brasileira: um estudo de ascensão social e classes sociais e grupos de prestigio. Salvador, Edufba.

BOURDIEU, Pierre \& Wacquant, Loïc. (2002), "Sobre as artimanhas da razão imperialista". Estudos Afro-Asiaticos, 24 (1): 15-33.

COLE, Sally. ([1947] 1994), "Introduction", in Ruth Landes (org.), The city of women, Albuquerque, The University of New Mexico Press, pp. vii-xxv.

CORRÊA, Mariza. (1987), História da antropologia no Brasil (1930-1960). Testemunhos: Emílio Willems e Donald Pierson. São Paulo/Campinas, Editora Revista dos Tribunais/Editora da Unicamp/Vértice.

. (2002), "Apresentação: esboços no espelho", in Ruth Landes (org.), A cidade das mulheres, 2 ed., Rio de Janeiro, Editora da UFRJ.

. (2003), Antropólogas e antropologia. Belo Horizonte, Editora da UFMG.
CORRÊA, Mariza \& Mello, Januária (orgs.). (2009), Querida Heloisa/Dear Heloisa: cartas de campo para Heloisa Alberto Torres. Campinas, Unicamp, Núcleo de Estudos de Gênero.

DANTAS, Beatriz G. (1988), Vovó nagô e papai branco: usos e abusos da Africa no Brasil. Rio de Janeiro, Graal.

DAVIS, John (ed.). (1958), African from the point of xiew of American Scholars. Paris, Présence Africaine.

DINES, Alberto. (2009), Morte no paraíso: a tragédia de Stefan Zweig. Rio de Janeiro, Rocco.

FRAZIER, E. Franklin. (1942a), "The negro family in Bahia, Brazil". American Sociological Review, 7: 465-478.

. (1942b), "Brazil has no race problems". Common Sense, 11: 363-365.

(1942c). "Some aspects of race relations in brazil". Phylon, (Third quarter): 284-295.

(1943), "Rejoinder to Melville J. Herskovits 'The negro in Bahia, Brazil: a problem in method'". American Sociological Review, 8: 402-204.

(1944), "Comparison of negro-white relations in Brazil and in the United States". Transactions of the New York Academy of Sciences, series 2, 6 (7): 251-269.

(1962), "A controversial question: do American negroes have what Africa needs?". Negro Digest, 62-75.

. (1966), The negro family in the United States. Chicago, The University of Chicago Press.

FRY, Peter. (2002), "Apresentação", in Ruth Landes (org.), A cidade das mulheres, 2 ed., Rio de Janeiro, Editora da UFRJ.

(2010), "Presentation" of the Special Issue of the on line journal Vibrant on Religion and Sexual Diversity, 7 (1). Disponível em <www.vibrant.org.br 2010>.

GERSHENHORN, Jerry. (2004), Melville J. Herskovits: and the racial politics of knowledge. Lincoln, University of Nebraska Press.

GOMES, Olivia da Cunha. (2005), "Do ponto de vista de quem? Diálogos, olhares e etnografias dos e nos arquivos". Estudos Históricos, 36: 7-32. 
GUIMARÃES, Antonio Sergio. (2007), “Africanism and racial democracy: the correspondence between Herskovits and Arthur Ramos (1935 1949)". Estudios Interdisciplinarios de America Latina y el Caribe, 19: 1-22.

. (2008), "A recepção de Fanon no Brasil e a identidade negra". Novos Estudos Cebrap, 81: 99-114.

HELLWIG, David J. (1992), African-American reflections on Brazil's racial paradise. Philadelphia, Temple University Press.

HERSKOVITS, Melville. (1943), "The negro in Bahia, Brazil: a problem in method". American Sociological Review, 8: 394-402.

. (1966), The new world negro: selected papers in Afro-American studies. Bloomington, Indiana, University of Indiana Press.

JACKSON, Walter. (1994), Gunnar Myrdal and America's conscience: social engineering and racial liberalism, 1938-1987. Chapel Hill, University of North Carolina Press.

LANDES, Ruth. (1964), The city of women. Albuquerque, University of New Mexico Press.

MAC DONALD, J. \& MAC DONALD, L. (1979), The black family in the Americas: a review of the literature. Londres, Sage.

MAIO, Marcos Chor. (1997), A história do Projeto Unesco: estudos raciais e ciências sociais no Brasil. Rio de Janeiro, tese de doutorado em Ciências Políticas, Iuperj.

. (1999), "O Projeto Unesco e a agenda das ciências sociais no Brasil dos anos 40 e 50". Revista Brasileira de Ciências Sociais, 14 (41): 141-158.

(2000), "The Unesco Project: social sciences and race studies in Brazil in the 1950s". Portuguese Literary \& Cultural Studies, 4/5: 51-64.

. (2001), Unesco and the study of race relations in Brazil: national or regional issue? Latin American Research Review, 36 (2): 118-136.

. (2011), "Florestan Fernandes, Oracy Nogueira, and the Unesco Project on race relations in São Paulo". Latin American Perspectives, 38: 136-149.

MARCELIN, Louis. (1999), A invenção da família afro-americana: família, parentesco e domestici- dade entre os negros do Recôncavo da Bahia. Rio de Janeiro, tese de doutorado em Antropologia, Museu Nacional, UFRJ.

PEREIRA, Claudio \& SANSONE, Livio (orgs.). (2007), Projeto Unesco no Brasil: textos críticos. Salvador, Edufba.

PIERSON, Donald. (1942), Negroes in Brazil: a study of race contact in Bahia. Chicago, University of Chicago Press.

PLATT, Anthony M. (1990), "Racism in academia: lessons from the life of E. Franklin Frazier". Monthly Review, 42 (4): 29-46.

. (1991), E. Franklin Frazier reconsidered. New Brunswick, NJ, Rutgers University Press.

. (1996), "The rebellious teaching career of E. Franklin Frazier". Journal of Blacks in Higher Education, 13: 86-90.

PRICE, Richard \& PRICE, Sally. (2003), The root of roots, or how Afro-American anthropology for its start. Chicago, Prickly Paradigm Press.

ROMO, Anadelia. (2009), "O que é que a Bahia representa? O Museu do Estado da Bahia e as disputas em torno da definição da cultura baiana”. Afro-Asia, 39: 115-151.

(2010), Brazil's living museum: race, reform, and tradition in Bahia. Chapel Hill, The University of North Carolina Press.

SANSONE, Livio. (2004), Negritude sem etnicidade. Rio de Janeiro/Salvador, Pallas/Edufba.

. (2007), "Contraponto baiano do açúcar e do petróleo: São Francisco do Conde, Bahia 50 Anos Depois", in Pereira e Sansone, Projeto Unesco no Brasil: textos críticos, Salvador, Edufba, pp. 194-218.

SPITZER, Leo. (1989), Lives in between: assimilation and marginality in Austria, Brazil and West Africa, 1780-1945. Cambridge, New York, Cambridge University Press.

TEELE, James E. (2002), E. Franklin Frazier and black bourgeoisie. Columbia/Londres, University of Missouri Press.

TURNER, Lorenzo Dow. (1943), "Some contacts of Brazilian ex-slaves with Nigeria, West Africa”. Journal of Negro History, XXVII: 55-67 . (1957), "The negro in Brazil". The Chicago Jewish Forum, 15: 232-236. 
. (1958), "African survivals in the new world with special emphasis on the arts", in John Davis (ed.), African from the point of view of American scholars, Paris, Présence Africaine, pp. 101-116.

. (2003), Africanisms in the Gullah dialect. Columbia, SC, University of South Carolina Press.

VALLADARES, Licia do Prado. (2010), "A visita do Robert Park ao Brasil, o 'homem marginal' e a Bahia como laboratório". Cadernos $C R H$, 23 (58): 35-49.

WADE-LEWIS, Margaret. (2007), Lorenzo Dow Turner: father of Gullah studies. Columbia, SC, University of South Carolina Press.

WAGLEY, Charles. (1952), Race and class in rural Brazil. Paris, Unesco.

WILLIAM, Daryle. (2001), Culture wars in Brazil: the First Vargas Regime 1930-1945. Durham/ Londres, Duke University Press.

YELVINGTON, Kevin. (2006), "The invention of Africa in Latin America and the Caribbean: political discourse and anthropological praxis, 1920-1940", in Kevin Yelvington (ed.), Afro-Atlantic dialogues: anthropology in the diaspora, Oxford, James Carrey. . (2007), "Melville J. Herskovits e a institucionalização dos estudos afro-americanos", in Pereira e Sansone, Projeto Unesco no Brasil: textos criticos, Salvador, Edufba, pp. 149-172.

ZWEIG, Stefan \& Zweig, Lotte. (2010), Stefan and Lotte Zweig's South American letters: New York, Argentina and Brazil, 1940-1942. Ed. Darién J. Davis e Oliver Marshall. Nova York, Continuum.

Fundos arquivisticos

ARCHIVES of Traditional Music (ATM), University of Indiana at Bloomington, Estados Unidos.

ARQUIVOS do Museu Nacional, Rio de Janeiro, Brasil.

BIBLIOTECA Nacional (Fundo Artur Ramos), Rio de Janeiro, Brasil.

CENTRO Schomburg para a Pesquisa sobre a Cultura Negra, New York Public Library, Frances
\& Melville Herskovits Papers, Estados Unidos. HOWARD University, Moorland-Spingarn Research Center, Franklin E. Frazier Papers, Estados Unidos.

MUSEU da Ciência, Rio de Janeiro, Brasil.

MUSEU da Comunidade de Anacostia, Instituto Smithsonian, Lorenzo Dow Turner Collection, Estados Unidos.

MUSEU Digital da Memória Africana e Afro-Brasileira, Brasil.

MUSEU Nacional de Arte Africana do Instituto Smithsonian, Melville Herskovits Photographic Collection, Estados Unidos.

NATIONAL Anthropological Archive (NAA), Instituto Smithsonian, Ruth Landes Papers e Marvin Harris Papers, Estados Unidos.

NORTHWESTERN University, University Archives, Melville Herskovits Papers e Lorenzo Dow Turner Papers, Estados Unidos.

UNIVERSITY of Massachusetts at Amherst, W. E. Du Bois Library, Special Collections and University Archives, W. E. Du Bois Papers, 18681963, Estados Unidos. 


\section{ESTADOS UNIDOS E BRASIL NO GANTOIS: O PODER E A ORIGEM TRANSNACIONAL DOS ESTUDOS AFRO-BRASILEIROS}

\section{Livio Sansone}

Palavras-chave: Frazier; Herskovits; Dow Turner; África; Candomblé.

Entre 1941 e 1943 a cidade de Salvador, na Bahia, tornou-se o local de uma batalha entre dois diferentes entendimentos sobre a integração racial nos Estados Unidos e sobre o lugar da África nesse processo. Franklin Frazier, o mais conhecido sociólogo norte-americano negro da época, estava empenhado em uma discussão com o igualmente famoso antropólogo, branco e judeu, Melville Herskovits, sobre as "origens" da chamada "família negra". Para tornar as coisas ainda mais complicadas, ambos baseavam seus argumentos em trabalhos de campo realizados com os mesmos informantes: o povo de santo do mesmo terreiro de candomblé em Salvador, o prestigiado e "tradicional" terreiro do Gantois, de nação queto-iorubá. A meio caminho entre os dois estava o linguista Lorenzo Dow Turner. Turner era amigo de Frazier, mas suas teorias acadêmicas estavam mais próximas das de Herskovits. $\mathrm{O}$ debate destacava aspectos interessantes relativos à forma pela qual a antropologia se define como disciplina, em comparação com a sociologia, e também à construção dos Estudos Africanos e dos Estudos Afro-brasileiros como campos de pesquisa acadêmica.

\section{BRAZIL AND THE UNITED STATES IN GANTOIS: POWER AND THE TRANSNATIONAL ORIGIN OF AFRO-BRAZILIAN STUDIES}

\section{Livio Sansone}

Keywords: Frazier; Herskovits: Dow Turner; Africa; Candomblé.

Between 1941 and 1943, the city of Salvador, Bahia, became the site of a battle between two different understandings on racial integration in the United States and the place of Africa in such process. Franklin Frazier, the most famous Black American sociologist at the time, was involved in an argument with the equally famous White and Jewish anthropologist Melville Herskovits on the "origins" of the so-called "Black family".To make things even more complex, both centered their contention on fieldwork done with the same informants: the members (the povo de santo) of the same Candomblé house of worship in Salvador - the prestigious and "traditional" Gantois terreiro, of the Ketu/Yoruba nation. In between the two of them was the linguist Lorenzo Dow Turner, who was a friend of Frazier, but whose scholarly theories were closer to Herskovits'. The debate highlighted interesting aspects regarding the way Anthropology defines itself as a discipline as compared to Sociology, as well as related to the construction of African studies and Afro-Brazilian studies as academic fields.

\section{LES ÉTATS-UNIS ET LE BRÉSIL DANS LA MAISON DU GANTOIS: LE POUVOIR ET L'ORIGINE TRANSNATIONALE DES ÉTUDES AFRO-BRÉSILIENNES}

\section{Livio Sansone}

Mots-clés: Frazier; Herskovits; Dow Turner; Afrique; Candomblé.

Entre 1941 et 1943 la ville de Salvador de Bahia a été la scène d'une bataille entre deux différents courants à propos de l'intégration raciale aux États-Unis et sur la place qu'occupe l'Afrique dans ce processus. Franklin Frazier, le sociologue nord-américain noir le plus renommé de cette époque, était engagé dans une discussion avec Melville Herskovits, anthropologue également célèbre, blanc et juif, sur les "origines" de la dénommée "famille noire". Pour rendre les choses encore plus compliquées, tous deux s'appuyaient sur des travaux réalisés au Brésil avec les mêmes interlocuteurs: les adeptes de la même maison ("terreiro") de candomblé à Salvador, la prestigieuse et "traditionnelle" maison du Gantois, de la nation queto-yoruba. À mi-chemin entre les deux se trouvait le linguiste Lorenzo Dow Turner. Turner était ami de Frazier, mais ses théories académiques étaient plus proches de celles de Herskovits. Le débat mettait en avant des aspects intéressants relatifs à la forme par laquelle l'anthropologie - en comparaison à la sociologie - se définit comme discipline et, aussi, à la construction des Études Africaines et des Études Afro-brésiliennes en tant que domaine de recherche académique. 